\title{
Separation of Co(II) from Zinc Plant Acidic Thiocyanate Leach Solutions Containing Co(II) and Ni(II) by Solvent Extraction Using Trioctylamine in Toluene
}

\author{
Volkan EYUPOGLU* ${ }^{*}$ and Recep Ali KUMBASAR \\ Department of Chemistry, Faculty of Science, Sakarya University, 54187 Adapazarı, Turkey. \\ (Received March 8, 2010; Accepted May 24, 2010)
}

In this study, a zinc plant purification cake (CINKUR Co. Turkey) was leached with sulphuric acid and an acidic leach solution containing $\mathrm{Zn}(\mathrm{II}), \mathrm{Fe}(\mathrm{II}), \mathrm{Pb}(\mathrm{II}), \mathrm{Al}(\mathrm{III})$, $\mathrm{Cu}(\mathrm{II}), \mathrm{Co}(\mathrm{II})$ and $\mathrm{Ni}$ (II) ions was obtained. After purification, ammonium thiocyanate and water were added to the remaining leach solution containing $\mathrm{Co}$ (II) and $\mathrm{Ni}$ (II) ions to adjust the chemical media and ion concentration. The acidic thiocyanate leach solutions were used in solvent extraction experiments. The various parameters were studied to determine the extraction and striping behaviour of $\mathrm{Co}(\mathrm{II})$. These parameters were diluent type, feed solution $\mathrm{pH}$, extractant concentration, mixing speed, phase ratio, stripping solution type and concentration and etc. Under optimum extraction conditions, the maximum extraction efficiency (99.9 \%) was achieved when using $5.0 \%(\mathrm{v} / \mathrm{v})$ TOA in toluene within $5 \mathrm{~min}$. The extracted $\mathrm{Co}(\mathrm{II})$ was stripped effectively from the organic phase using $5.0 \mathrm{M} \mathrm{NH}_{3}$ solution.

Keywords: solvent extraction, acidic thiocyanate solutions, trioctylamine, $\mathrm{Co}(\mathrm{II}) / \mathrm{Ni}(\mathrm{II})$ separation, zinc plant purification cake

\section{Introduction}

Cobalt and nickel are among the most important nonferrous metals. The separation of cobalt from nickel in aqueous solution has always been a problem in hydrometallurgy. Hydrometallurgical methods of leaching using sulphate, chloride-sulphate, and chloride systems result in leach liquors containing mainly nickel and cobalt in association with some impurities, such as copper, iron, and aluminium [1]. Usually, the majority of these impurities are removed by precipitation with lime, while the copper is cemented out with cobalt powder and recovered by filtration [2]. The purified leach liquors contain both $\mathrm{Co}$ (II) and $\mathrm{Ni}$ (II) ions. It is very difficult to obtain pure cobalt and nickel compounds from such solutions because of the similar physicochemical properties of these metals $[3,4]$. Using classical methods, such as precipitation,

\footnotetext{
* Address correspondence to Volkan Eyupoglu, Sakarya University. Science and Lecture Fac. Chemistry Department 54187 Sakarya, Turkey. Tel.: +90264 2956065, Fax:+90264 2955950, E-mail: veyupoglu@sakarya.edu.tr
} 
oxidation, and crystallization, it is impossible to separate the nickel-cobalt pair in a simple and economical way. Solvent extraction seems to be the most efficient method for separation of $\mathrm{Co}$ (II) and $\mathrm{Ni}$ (II) ions from aqueous solutions, including leach liquors [5,6]. Generally, cobalt is preferentially removed with a suitable extractant, leaving nickel behind. Among a large number of extracting agents studied, organophosphorus compounds have demonstrated the best $\mathrm{Co}(\mathrm{II}) / \mathrm{Ni}(\mathrm{II})$ separation ability. Di-2-ethylhexyl phosphoric acid (D2EHPA) was the first widely used extractant for recovery of $\mathrm{Co}$ (II) and $\mathrm{Ni}(\mathrm{II})$ and for their separation [7]. Nevertheless, the process of $\mathrm{Co}(\mathrm{II})$ and $\mathrm{Ni}$ (II) separation using (D2EHPA) as extracting agent requires very strict $\mathrm{pH}$ control and relatively high operational temperatures. Afterward, the development of phosphonic and phosphinic acid extractants led to improvement in $\mathrm{Co}(\mathrm{II}) / \mathrm{Ni}$ (II) separation factors. $\mathrm{Co}$ (II) was successfully separated from $\mathrm{Ni}$ (II) from sulphate solutions using the 2-ethylhexyl phosphonic acid mono-2ethylhexyl ester [8] and the bis(2,4,4-trimethylpentyl) phosphinic acid (Cyanex 272) [9,10].

It has been reported that ternary amines are more efficient extractants for $\mathrm{Co}$ (II) and $\mathrm{Ni}$ (II) when compared to secondary and primary ones [11]. Tertiary amines used as extractant agent in this work may be considered as a mixture of organic amines whose major components are ternary amines with special emphasis on trioctylamines [12]. Saji et al. have proposed xylenes and its derivatives as diluents for extractants because of their positive effects on extraction mixing and settling phases. m-xylene was chosen as a diluent for Alamine 336 with respect to its tolerable toxicity and affordable price [13].

The transport of metal ions from wastewater solutions by solvent extraction (SX) proceses has been a subject of many studies over recent years. Hundreds of cation separation systems have been published in the literature, but only a few examples are known for the separation of anions which concentrated on anion separation. The removal of toxic elements such as thiocyanate anions by SX proceses has been of great interest in recent years [14]. In view of these aspect, the separation of metals by the SX technique has been drawn considerable attention $[15,16]$.

In this present study, we investigated the solvent extraction of $\mathrm{Co}(\mathrm{II})$ ions from aqueous thiocyanate leach solutions containing divalent $\mathrm{Co}$ (II) and $\mathrm{Ni}$ (II) mixture using trioctylamine (TOA) as extractant in toluene as diluent. We systematically monitored the effect of several extraction proceses parameters: diluent type, feed solution $\mathrm{pH}$, extractant concentration, mixing speed, phase ratio $\left(V_{o} / V_{a}\right)$, thiocyanate concentration in the feed solution, equilibration time. The extracted Co(II) ions were removed from the organic phase using $\mathrm{NH}_{3}$ as an effective stripping agent.

\section{Experimental}

\subsection{Reagents}

The organic phase was composed of an extractant and a diluent. The extractant was TOA which was purchased from Merck. Diluents (xylene, toluene, dichloromethane) were purchased from Reidel-De Haen. Kerosene was commercially available (density $830 \mathrm{~kg} / \mathrm{m}^{3}$ and viscosity $7.3 \mathrm{mPa} . \mathrm{s}$ at $20^{\circ} \mathrm{C}$ ). $\mathrm{NH}_{3}, \mathrm{NH}_{4} \mathrm{SCN}$, acetic acid $(\mathrm{AcH})$, sodium acetate $(\mathrm{NaAc}), \mathrm{NaOH}$ and all other chemicals were purchased from Merck and were used directly as received from the manufacturer. 


\subsection{Feed solution preparation}

The zinc plant purification cake obtained from (CINKUR Co., Turkey), composed of average of $20 \% \mathrm{Zn}(\mathrm{II}), 10 \% \mathrm{Cu}(\mathrm{II}), 1 \% \mathrm{~Pb}(\mathrm{II}), 0.1 \% \mathrm{Fe}(\mathrm{III}), 2.2 \% \mathrm{Co}(\mathrm{II}), 3.1 \% \mathrm{Ni}(\mathrm{II}), 3.0 \% \mathrm{Cd}(\mathrm{II})$, and $1 \%$ $\mathrm{Al}(\mathrm{II})$ on a mass basis, was leached with a $2 \mathrm{M}$ sulphuric acid solution using a solid/liquid ratio of $1 / 4$ at $85{ }^{\circ} \mathrm{C}$ for $120 \mathrm{~min}$, giving an acidic leach solution containing $\mathrm{Zn}(\mathrm{II}), \mathrm{Cu}(\mathrm{II}), \mathrm{Pb}(\mathrm{II}), \mathrm{Fe}(\mathrm{III}), \mathrm{Co}(\mathrm{II})$, $\mathrm{Ni}(\mathrm{II}), \mathrm{Cd}(\mathrm{II})$, and $\mathrm{Al}(\mathrm{III})$ ions. In order to obtain relatively rich cakes in this process, except for cadmium, cobalt, and nickel, the other metal ions in the acidic leach solution were gradually precipitated by adding various reagents and adjusting the $\mathrm{pH}$ of this solution (the $\mathrm{pH}$ of the acidic leach solutions was adjusted by HANNA Instruments $\mathrm{pH} 211$ Microprocessor $\mathrm{pH}$ meter). The decrease of concentration of $\mathrm{Fe}(\mathrm{III}), \mathrm{Al}(\mathrm{III}), \mathrm{Cu}(\mathrm{II}), \mathrm{Zn}(\mathrm{II}), \mathrm{Pb}$ (II) ions in the feed solution was not studied, but it was observed that the corresponding concentrations of $\mathrm{Cd}(\mathrm{II}), \mathrm{Co}$ (II) and $\mathrm{Ni}(\mathrm{II})$ in the feed solution scarcely changed. After precipitation process, adjusting the $\mathrm{pH}$ of leach solution, cadmium was separated by solvent extraction. The final leach solution contained about $3040 \mathrm{mg} / \mathrm{L} \mathrm{Co}$ (II) and 3078 $\mathrm{mg} / \mathrm{L} \mathrm{Ni(II).} \mathrm{Then,} \mathrm{ammonium} \mathrm{thiocyanate,} \mathrm{cobalt} \mathrm{and} \mathrm{nickel} \mathrm{concentrations} \mathrm{and} \mathrm{the} \mathrm{pH}$ of the final acidic leach solution were fixed as desired by adding ammonium thiocyanate and acetic acid-sodium acetate buffer solution. Ammonium thiocyanate was added into the feed mixture to increase the selectivity of cobalt against nickel[22]. The AcH/NaAc buffer solution used was essential to maintain the desired feed $\mathrm{pH}$, which was very critical for $\mathrm{Co}$ (II) and $\mathrm{Ni}$ (II) separations. Thus, the acidic thiocyanate leach solutions were prepared by dilution of stock acidic leach solution and were used as feed solutions in (SX) experiments.

\subsection{Extraction procedure}

The experiments were carried out in water jacketed beakers, holding around $50 \mathrm{~mL}$ in the internal beaker. The internal beaker is encapsulated by a water jacket with two srewthread side ports for circulating a temperature controlling fluid through. Thermal control was supplied with a heater and circulating water bath. $20 \mathrm{~mL}$ of zinc plant leach solution was diluted from the stock acidic leach solution to desired Co(II) and $\mathrm{Ni}$ (II) concentration and in defined concentration of (TOA) was diluted in toluene to be $20 \mathrm{~mL}$ total volume. All the extraction and stripping experiments were carried out batchwise at the temperature of

$25 \pm 0.1{ }^{0} \mathrm{C}$. All aqueous solutions were prepared using deionised water. The phases were agitated by a digitally controled magnetic stirrer (DAIHAN MSH-20D) at constant stirring speed. After 5 min, the organic and the aqueous phases were separated and the metal ion concentrations were determined from the aqueous phase. The concentrations of the metal ions in the organic phase were calculated from the difference of the metal ion concentrations in the aqueous phase before and after extraction. The results were expressed as percentage of extracted metals.

\subsection{Analytical method}

After equilibration, the phases were allowed to separate and $\mathrm{Co}(\mathrm{II})$ and $\mathrm{Ni}(\mathrm{II})$ contents in the raffinate were determined by atomic absorption spectrometer (AAS) (Shimadzu AA-6701F model, Tokyo, Japan) in semi-automatic mode. 


\section{Results and discussion}

\subsection{Stoichiometry of the extracted and stripped species}

To determine the nature of the extracted species, we were studied varied the TOA concentration from $1.12 \times 10^{-5} \mathrm{~mol} / \mathrm{L}$ to $1.12 \times 10^{-3} \mathrm{~mol} / \mathrm{L}$ in toluene, the $\mathrm{pH}$ from 3.8 to 4.5 and the $\mathrm{SCN}^{-}$concentration from 0.1 $\mathrm{mol} / \mathrm{L}$ to $0.5 \mathrm{~mol} / \mathrm{L}$. From these experiments, disturbution ratios were calculated for extracted $\mathrm{Co}(\mathrm{II})$. The plot of $\log D$ versus $\log [\mathrm{TOA}], \log D$ versus $\log \left[\mathrm{H}^{+}\right]$and $\log D$ versus $\log \left[\mathrm{SCN}^{-}\right]$gave a straight line having a slope of $1.986 \sim 2.0,1.56 \sim 2.0$ and $4.52 \sim 4.0$, respectively (Fig. 1, 2 and 3). indicating a mole ratio of $\mathrm{Co}(\mathrm{II})-\mathrm{SCN}^{-} ; 1: 4, \mathrm{TOA}-(\mathrm{SCN})_{4}{ }^{2-} 2: 1$ and TOA- $\mathrm{H}^{+} ; 2: 2$. According to the stoichiometric plots, the coordination reaction (Eq. (1)) is inferred to have occurred during the extraction;

$$
2 \mathrm{R}_{3} \mathrm{~N}_{(\mathrm{org})}+2 \mathrm{H}_{(\mathrm{aq})}^{+}+\mathrm{Co}_{(\mathrm{aq})}^{2+}+4 \mathrm{SCN}_{(\mathrm{aq})}^{-} \leftrightarrow\left[\left(\mathrm{R}_{3} \mathrm{NH}\right)_{2} \mathrm{Co}(\mathrm{SCN})_{4}\right\rfloor_{(\mathrm{org})}
$$

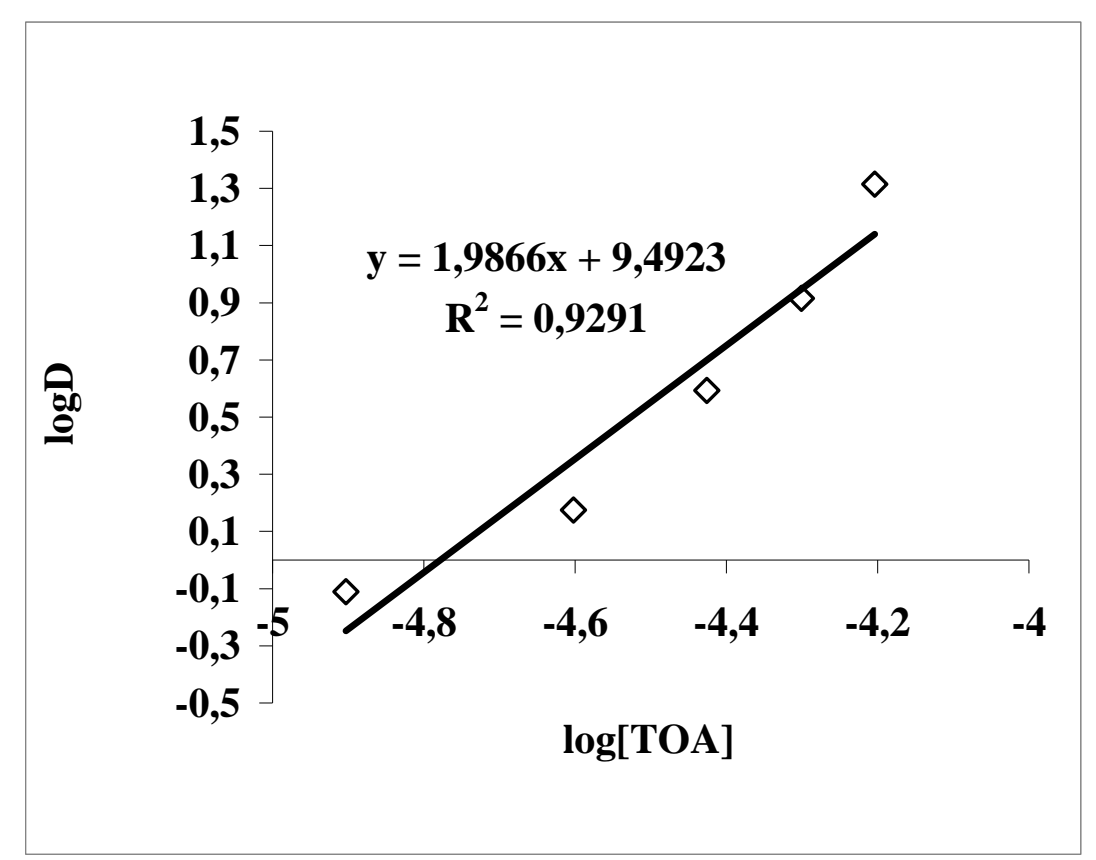

Figure 1. Log- $\log$ plot between distribution ratio and extractant concentration; $\mathrm{SCN}^{-}$concentration of the acidic leach solution: $0.5 \mathrm{M}$; $\mathrm{Co}$ (II) concentration of the acidic leach solution: $1006 \mathrm{mg} / \mathrm{L}$; $\mathrm{pH}$ of the acidic leach solution: 4.5; phase ratio: 1.0; equilibration times 5 min. 


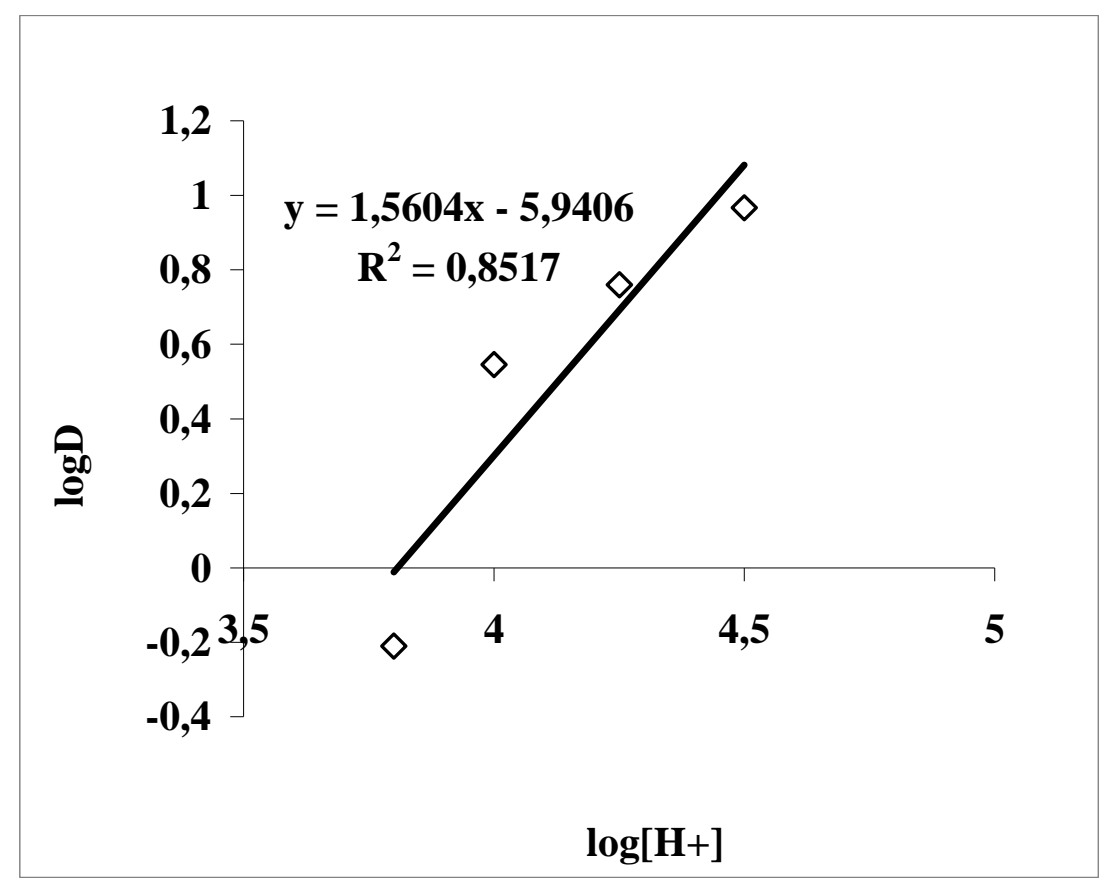

Figure 2. $\log -\log$ plot between distribution ratio and $\mathrm{pH}$; TOA: $5.0 \%(\mathrm{v} / \mathrm{v})$; toluene: $95 \%(\mathrm{v} / \mathrm{v})$; $\mathrm{SCN}^{-}$ concentration of the acidic leach solution: $0.5 \mathrm{M}$; Co(II) concentration of the acidic leach solution: 1006 $\mathrm{mg} / \mathrm{L}$; phase ratio: 1.0; equilibration times $5 \mathrm{~min}$.

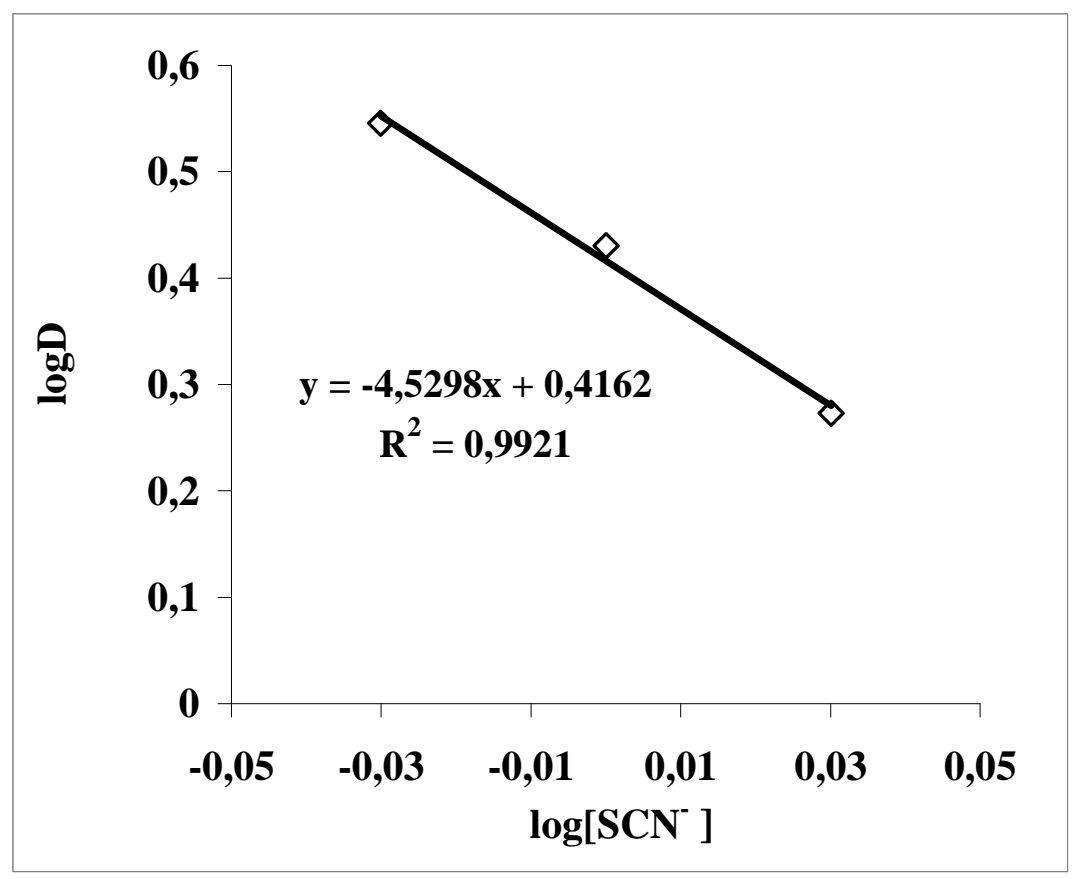

Figure 3. $\log -\log$ plot between distribution ratio and $\mathrm{SCN}^{-}$concentration; TOA: $5.0 \%(\mathrm{v} / \mathrm{v})$; toluene: $95 \%(\mathrm{v} / \mathrm{v}) ; \mathrm{Co}(\mathrm{II})$ concentration of the acidic leach solution: $1006 \mathrm{mg} / \mathrm{L} ; \mathrm{pH}$ of the acidic leach solution: 4.5; phase ratio: 1.0; equilibration times $5 \mathrm{~min}$. 
The equilibrium constant of the above reaction, $K_{e x}$, can be given as a function of molar concentration (Eq. (2)), provided that the ionic strength of the aqueous solution is kept constant:

$$
\mathrm{K}_{\mathrm{ex}}=\frac{\left[\left(\mathrm{R}_{3} \mathrm{NH}\right){ }_{2} \mathrm{Co}(\mathrm{SCN})\right]_{(\mathrm{org})}}{\left[\mathrm{Co}^{2+}\right]_{(\mathrm{aq})}\left[\mathrm{R}_{3} \mathrm{~N}_{(\text {org })}^{2}\left[\mathrm{H}^{+}\right]_{(\text {aq })}^{2}\left[\mathrm{SCN}^{-}\right]_{(\mathrm{aq})}^{4}\right.}
$$

Substituting the distribution coefficient, $D$, defined as the ratio of the metal concentrations in organic phase and aqueous phase, in Eq. (3) gives:

$$
\mathrm{D}=\mathrm{K}_{\mathrm{ex}}\left[\mathrm{R}_{3} \mathrm{~N}\right]_{(\mathrm{org})}^{2}\left[\mathrm{H}^{+}\right]_{(\mathrm{aq})}^{2}[\mathrm{SCN}-]_{(\mathrm{aq})}^{4}
$$

Rearranging by taking the logarithms, Eq. (4) becomes:

$$
\log \mathrm{D}=\log \mathrm{K}_{\text {ex }}+2 \log \left[\mathrm{R}_{3} \mathrm{~N}\right]+2 \log \left[\mathrm{H}^{+}\right]_{(\mathrm{aq})}+4 \log \left[\mathrm{SCN}^{-}\right]_{(\mathrm{aq})}
$$

It is therefore concluded that two moles of extractant coordinate the $\mathrm{Co}(\mathrm{SCN})_{4}{ }^{2-}$ molecule around the Co(II) ion with unshared lone pairs of electrons from the nitrogen atoms of four TOA extractants, retaining the coordination sphere around the metal ion [17]. The species extracted depends on many factors, such as the equilibrium $\mathrm{pH}$, the extractant and metal concentrations, and the solvent phase properties [18]. It is known that extractants such as amines and solvating extractants become polymerized or self-associated in organic diluents [19].

During the stripping, various concentrations of $\mathrm{NH}_{3}$ and triethanolamine (TEA) solutions in the range of $1.0 \sim 6.0 \mathrm{~mol} / \mathrm{L}$ were used. According to the experimental results, $\mathrm{NH}_{3}$ was determined as an effective stripping agent. The $\left(\mathrm{R}_{3} \mathrm{NH}\right)_{2} \mathrm{Co}(\mathrm{SCN})_{4}$ complex dissociates to regenerate the TOA carrier. The plot of $\log$ $D$ versus $\log \left[\mathrm{OH}^{-}\right]$gave a straight line having a slope of $2.41 \sim 2.0$. To dissociate the $\left(\mathrm{R}_{3} \mathrm{NH}\right)_{2} \mathrm{Co}(\mathrm{SCN})_{4}$ complex, $\mathrm{OH}^{-}$ions participated to the stripping reaction in 1:2 mole ratio. The stripped $\mathrm{Co}$ (II) ions formed a stable $\mathrm{Co}\left(\mathrm{NH}_{3}\right)_{6}{ }^{2+}$ complex in the presence of the $\mathrm{NH}_{3}$ stripping solution. According to the stoichiometric plot, we infer that the following coordination type reaction (Eq. (5)) occurred during the stripping: 


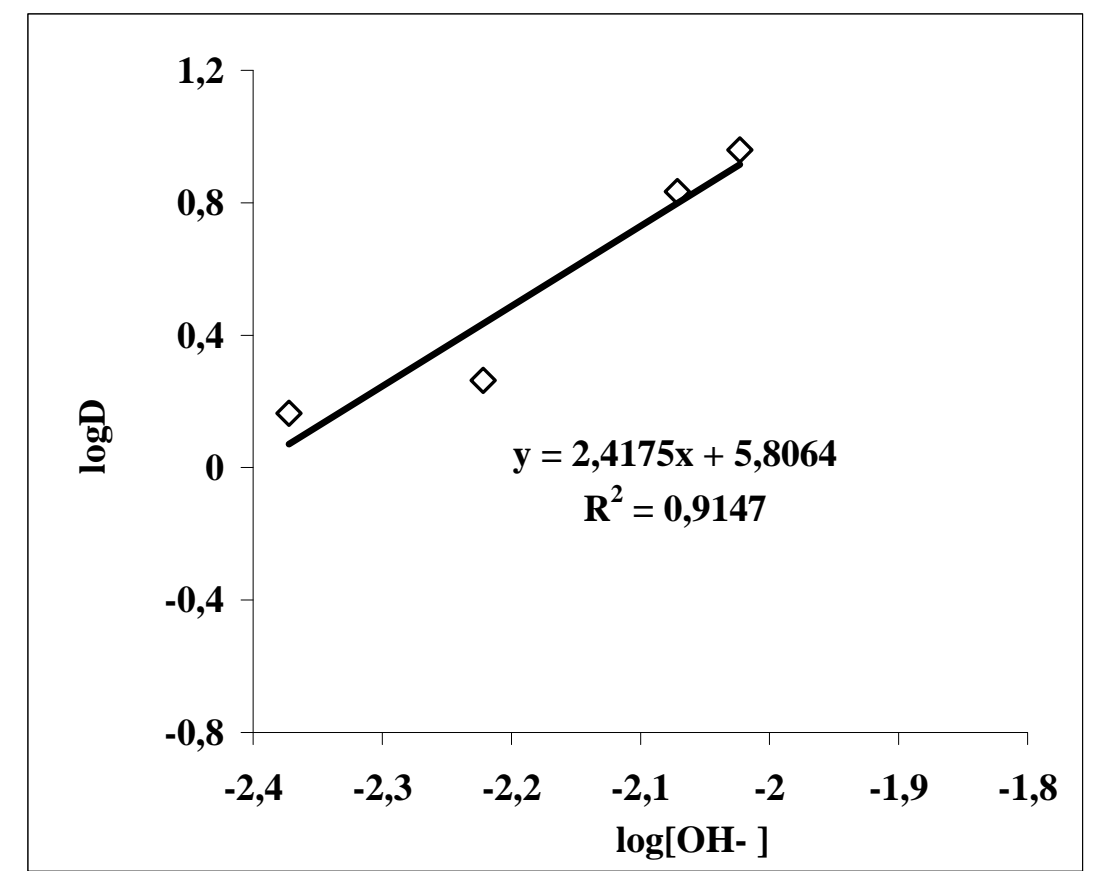

Figure 4. $\log -\log$ plot between distribution ratio and $\mathrm{pOH}$; TOA: $5 \%(\mathrm{v} / \mathrm{v})$; toluene: $95 \%(\mathrm{v} / \mathrm{v})$; $\mathrm{SCN}^{-}$ concentration of the acidic leach solution: $0.5 \mathrm{M}$; Co(II) concentration of loaded organic phase: $1010 \mathrm{mg} / \mathrm{L}$; $\mathrm{pH}$ of the acidic leach solution: 4.5; phase ratio: 1.0; equilibration times $5 \mathrm{~min}$.

Stripping reaction:

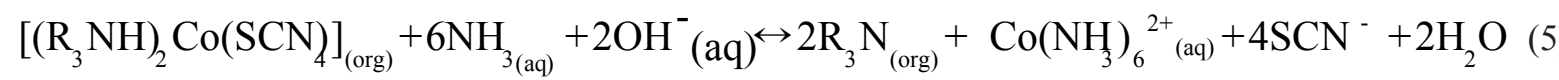

\subsection{Effect of the diluent}

The behavior of TOA mixed with different diluents, which were dichloromethane, toluene, kerosene, xylene and benzene was studied for the extraction of Co(II) from acidic thiocyanate leach solution. The results presented in Fig 5. show that dichloromethane was not a suitable diluent. Other diluents were found effective for (TOA). Eventually, in the present work, toluene was selected as diluent for TOA due to its good extractability, high polarity, solvation and dissolution properties towards the TOA-Co(SCN $)_{4}{ }^{2-}$ complexes[2]. 


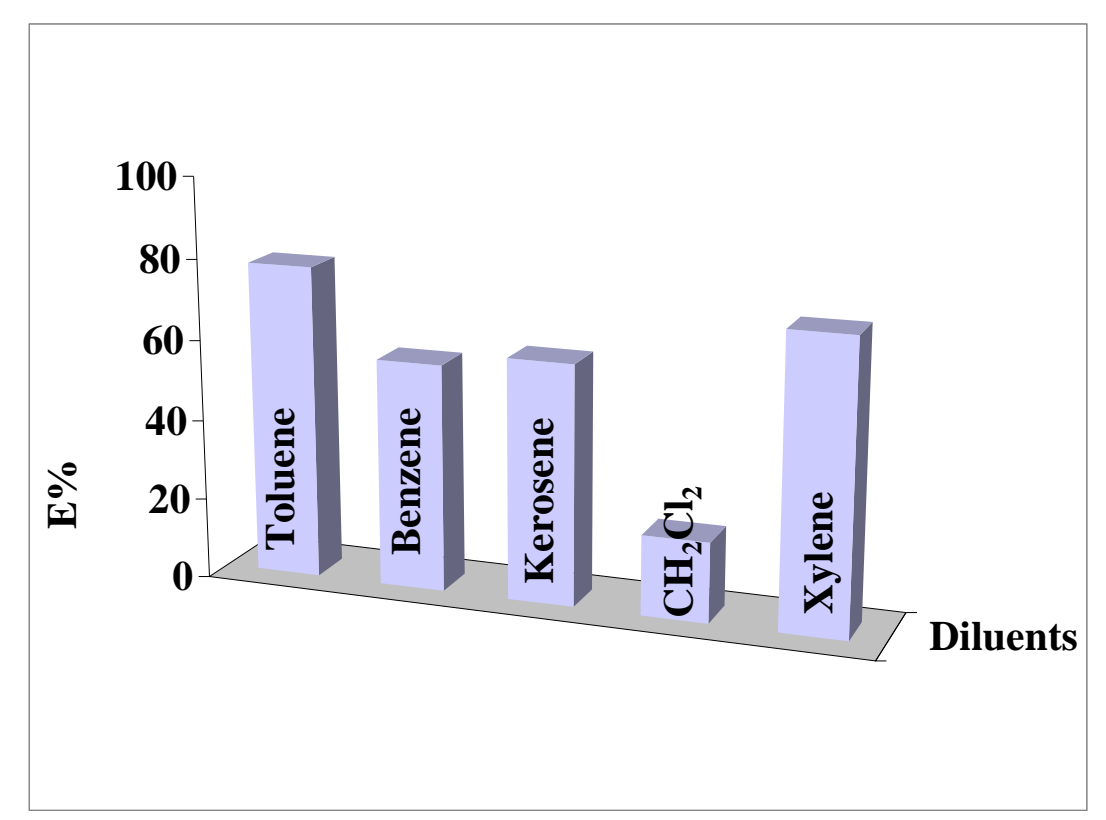

Figure 5. Effect of diluent (TOA: $1.5 \%(\mathrm{v} / \mathrm{v})$ in suitable diluent; mixing speed: $1000 \mathrm{rpm}$; $\mathrm{SCN}^{-}$ concentration of the acidic leach solution: $0.5 \mathrm{M}$; $\mathrm{Co}$ (II) concentration of the acidic leach solution: 1006 $\mathrm{mg} / \mathrm{L} ; \mathrm{pH}$ of the acidic leach solution: 4.0; phase ratio: 1.0; equiliration times $5 \mathrm{~min}$.

\subsection{Effect of mixing speed}

The mixing speed experiments were carried out with by a digitally controled magnetic stirrer (DAIHAN MSH-20D) and magnetic impeller at constant stirring speed. The effect of mixing speed on the extraction was shown in Fig. 7. The first observation is that the extraction of Co(II) increased with increasing of mixing speed. At the lower mixing speeds up to $500 \mathrm{rpm}$, the extraction was negligible. The second is that the maximum extraction at the end of the process time was obtained with a mixing speed of $1000 \mathrm{rpm}$. At the upper mixing speeds of between $1000 \mathrm{rpm}$ and 1500rpm, the extraction percentage of Co(II) was approximately stable. Therefore, the optimum value for mixing speed was determined as 1000 rpm. 


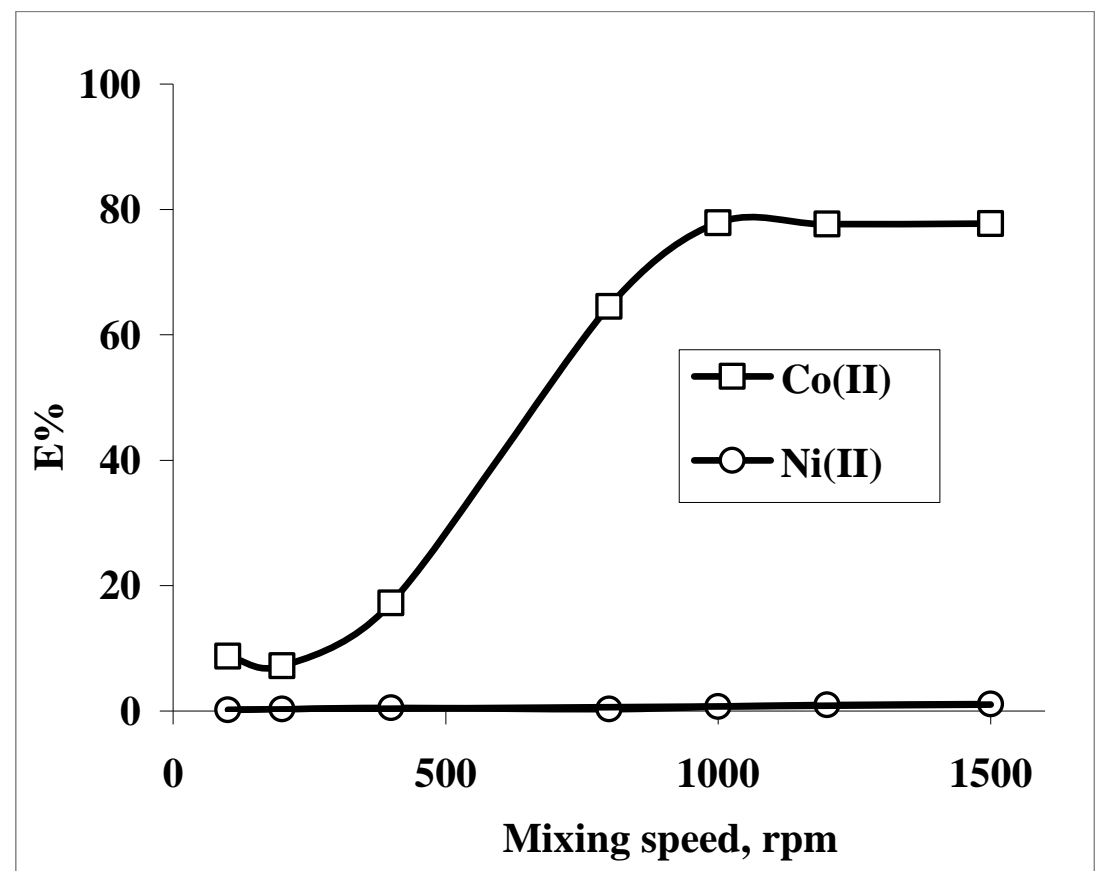

Figure 6. Effect of mixing speed (TOA: $1.5 \%(\mathrm{v} / \mathrm{v})$; toluene: $98.5 \%(\mathrm{v} / \mathrm{v}) ; \mathrm{SCN}^{-}$concentration of the acidic leach solution: $0.5 \mathrm{M}$; $\mathrm{Co}(\mathrm{II})$ concentration of the acidic leach solution: $1006 \mathrm{mg} / \mathrm{L} ; \mathrm{pH}$ of the acidic leach solution: 4.0; phase ratio: 1.0; equilibration times $5 \mathrm{~min}$

\subsection{Effect of SCN ${ }^{-}$concentration in the acidic leach solution}

The effect of the $\mathrm{SCN}^{-}$concentration in the acidic leach solution on the Co(II) extraction was investigated from $0.10 \mathrm{M}$ to $2.0 \mathrm{M}$. As seen from Fig. 8, with increasing the $\mathrm{SCN}^{-}$concentration from 0.10 $\mathrm{M}$ to $0.5 \mathrm{M}$, the percentage of cobalt extraction also increases with further increase of the $\mathrm{SCN}^{-}$ concentration in the acidic leach solution, extraction of Co(II) slowly decreased [20]. In acidic leach solution, cobalt ions react with $\mathrm{NH}_{4} \mathrm{SCN}$ to form the tetrahedral cobalt(II) thiocyanate complex, $\mathrm{Co}(\mathrm{SCN})_{4}{ }^{2-}$, whereas in case of nickel ions they hardly form the thiocyanate complex [22-24]. Preston [20] stated that the cobalt is extracted as the tetrahedral anion, $\mathrm{Co}(\mathrm{SCN})_{4}{ }^{2-}$, from the examination of electronic spectra of organic extract, while nickel forms an octahedral complex, probably $\mathrm{Co}(\mathrm{SCN})_{4} \cdot\left(\mathrm{H}_{2} \mathrm{O}\right)_{2}{ }^{2-}$. This is in agreement with the reports of $\mathrm{Zhu}[4]$ that the $7 \mathrm{~d}$ electron of $\mathrm{Co}^{2+}$ is the one of the most favoured ions for the tetrahedral configuration from the viewpoint of the ligand field theory and that the steric hindrance is the only factor which could weaken the octahedral configuration. So, cobalt is more preferably extracted into the organic phase than nickel. 


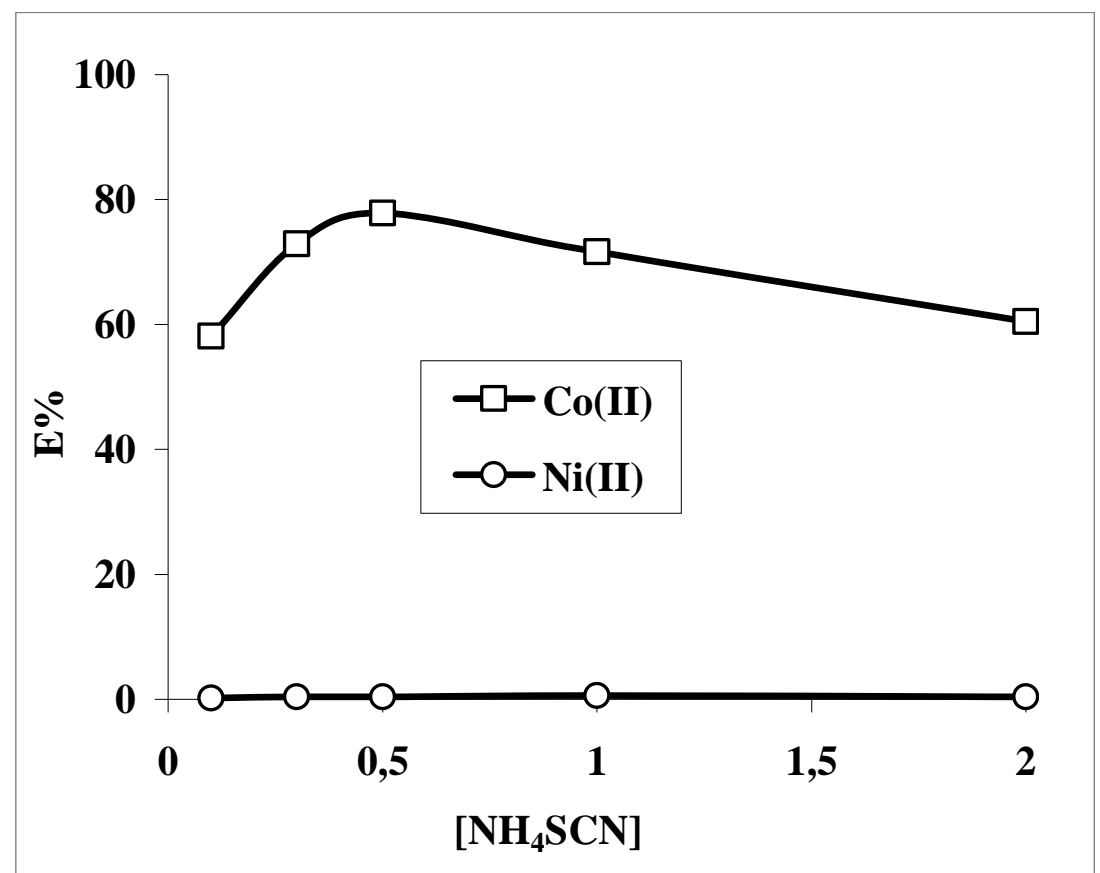

Figure 7. Effect of $\mathrm{NH}_{4} \mathrm{SCN}$ concentration (TOA: $1.5 \%(\mathrm{v} / \mathrm{v})$; toluene: $98.5 \%(\mathrm{v} / \mathrm{v})$; $\mathrm{Co}(\mathrm{II})$ concentration of the acidic leach solution: $1006 \mathrm{mg} / \mathrm{L}$; $\mathrm{pH}$ of the acidic leach solution: 4.0; phase ratio: 1.0; equilibration times 5 min.

\subsection{Effect of the acidic leach solution pH}

The $\mathrm{pH}$ of the acidic thiocyanate leach solution has a profound effect on the extraction behaviour. In this work, the $\mathrm{pH}$ of the acidic thiocyanate leach solution was varied from 3.8 to 6.0 and the obtained results were shown in Fig. 9 (to maintain constant $\mathrm{pH}$ of the acidic thiocyanate leach solution, the $\mathrm{NaAc} / \mathrm{AcH}$ buffer solution was used). From Fig. 9, it was observed that by increasing $\mathrm{pH}$ of the feed solution from 3.80 to 4.50 the percentage of $\mathrm{Co}$ (II) extraction increased. With further increase in acidic leach solution $\mathrm{pH}$ from 4.5 to 6.0 , the rate of cobalt extraction started to slightly decrease. Because, increase in proton concentration in the feed solution will form a species like $\mathrm{H}_{2} \mathrm{Co}(\mathrm{SCN})_{4}$ which may not ionize completely at higher acid concentration to form a complex with TOA. Hence the extraction will decrease with the increase in acid concentration. On the other hand, the decrease in the extraction with the decrease in proton concentration can be explained by the fact that the concentration of $\mathrm{H}_{2} \mathrm{Co}(\mathrm{SCN})_{4}$ complex decrease due to the less availability of protons for the reaction Therefore, $\mathrm{pH} 4.5$ was selected as the best $\mathrm{pH}$ value and was used as the $\mathrm{pH}$ of the feed solution in the following experiments. 


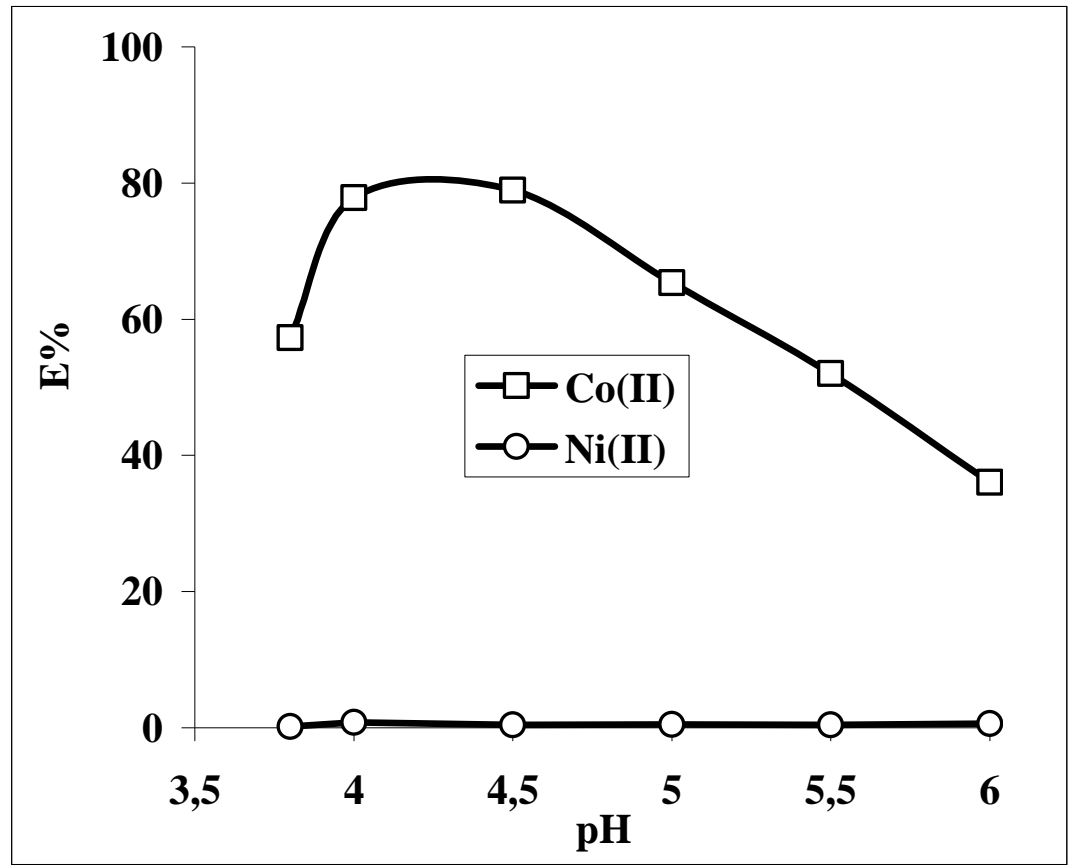

Figure 8. Effect of eqilibration $\mathrm{pH}\left(\mathrm{TOA}: 1.5 \% \mathrm{v} / \mathrm{v}\right.$; toluene: $98.5 \%(\mathrm{v} / \mathrm{v})$; $\mathrm{SCN}^{-}$concentration of the acidic leach solution: $0.5 \mathrm{M}$; $\mathrm{Co}(\mathrm{II})$ concentration of the acidic leach solution: $1006 \mathrm{mg} / \mathrm{L}$; phase ratio: 1.0; equilibration time $5 \mathrm{~min}$.

\subsection{Effect of extractant concentration}

To investigate the effect of the extractant concentration on the extraction of Co(II) ions, the (TOA) concentration was varied in the range from 0.1 to $10 \%(\mathrm{v} / \mathrm{v})$ in toluene as diluent (Fig. 10). The maximum extraction (99.9\%) was achieved at $5.0 \%$ TOA in toluene. The extractant concentration in the organic phase played a vital role in the overall extraction of the metal ions because it was necessary for the amine to be sufficiently available for the formation and extraction of the complex $\left(\mathrm{R}_{3} \mathrm{NH}\right)_{2} \mathrm{Co}(\mathrm{SCN})_{4}$ into the organic phase. A further increase in the TOA concentration from 5.0 to $10 \%(\mathrm{v} / \mathrm{v})$ did not give any further positive effect on the extraction of Co(II) ions. Although the diluent (toluene) was not directly involved in the extraction of $\mathrm{Co}(\mathrm{II})$ species, it modified the viscosity and the surface tension properties of the organic phase, leading to longer phase disengagement time and negligible entrainment [21]. Therefore, the percentage of extracted metal can be considered a response to the percentage of active extractant in the diluent. 


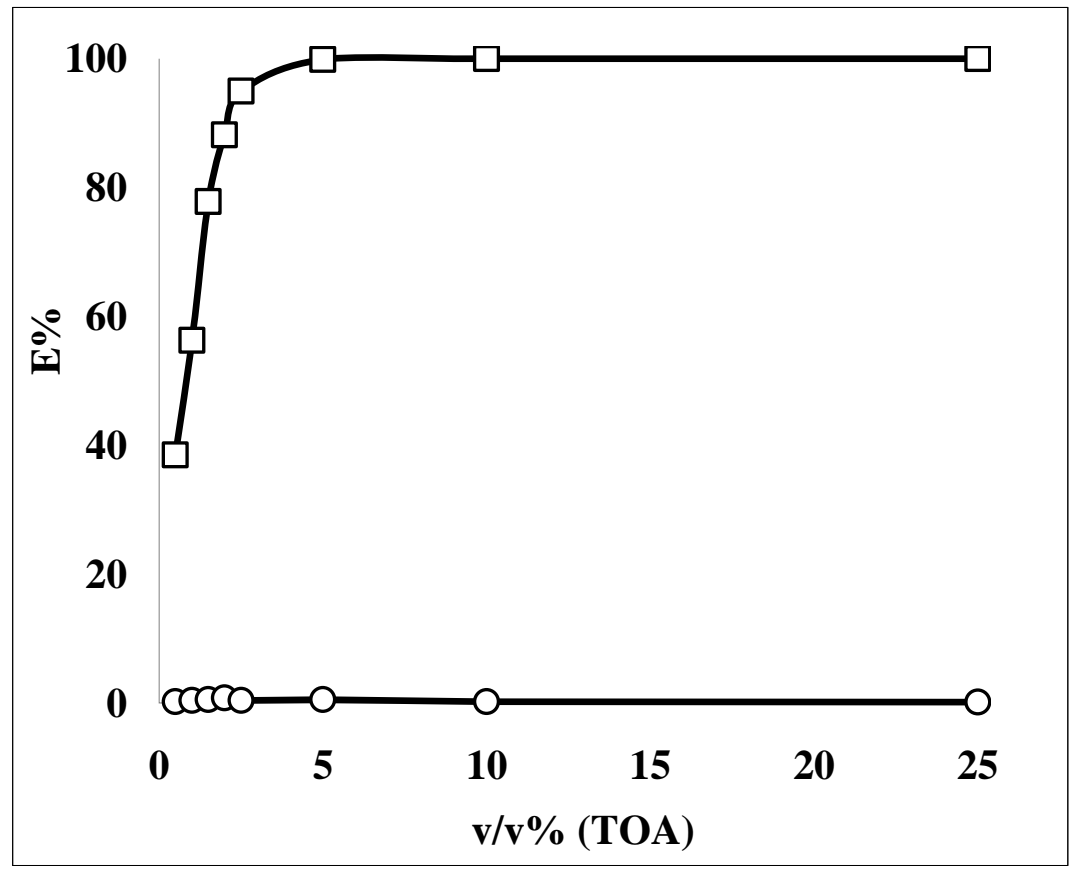

Figure 9. Effect of TOA concentration ( $\mathrm{SCN}^{-}$concentration of the acidic leach solution: $0.5 \mathrm{M}$; $\mathrm{Co}$ (II) concentration of the acidic leach solution: $1006 \mathrm{mg} / \mathrm{L}$; $\mathrm{pH}$ of the acidic leach solution: 4.0; phase ratio: 1.0; equilibration times $5 \mathrm{~min}$.

\subsection{Effect of phase ratio}

In order to determine the number of stages that are required at a chosen volume phase ratio, the $\mathrm{Co}(\mathrm{II})$ extraction isotherm was obtained at different $\mathrm{O} / \mathrm{A}$ phase ratios from 1:4 4:1 contacting the aqueous feed $(1.006 \mathrm{~g} / \mathrm{L} \mathrm{Co}$ and $1.018 \mathrm{~g} / \mathrm{L} \mathrm{Ni})$ and organic phases $(1.5 \%(\mathrm{v} / \mathrm{v}) \mathrm{TOA}$ in toluene) at an equilibrium $\mathrm{pH} 4.5$ (Fig. 11). As seen Fig 11, it can be concluded that Co(II) extraction increased from $25.3 \%$ to $99.2 \%$ at an increase of $\mathrm{O} / \mathrm{A}$ ratio from 1:4 to 2:1. A further increase in the phase ratio from 2:1 to 4:1 did not result in any positive effect on the extraction of Co(II) ions. From the McCabe-Thiele plot (Fig. 12), the results also indicate that $\mathrm{Co}$ (II) extraction efficiency $>>99 \%$ can be achieved, if the extraction is performed for three counter current stages at $\mathrm{O} / \mathrm{A}$ phase ratio of 2:1, where $\mathrm{Co}(\mathrm{II})$ extraction efficiency in single stage is about $99 \%$. 


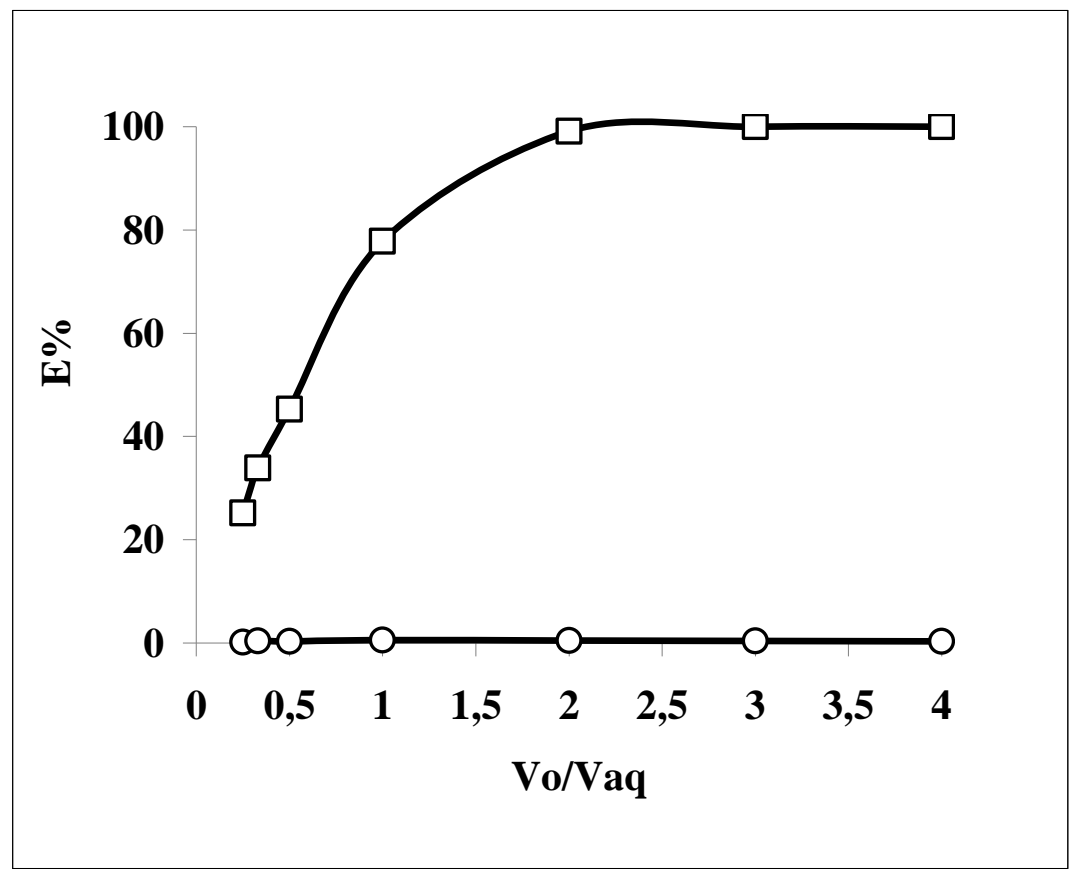

Figure 10. Effect of phase ratio in the acidic leach solution on the extraction rate of Co (TOA: 1,5 \%(v/v); toluene: $98.5 \%(\mathrm{v} / \mathrm{v})$; $\mathrm{SCN}^{-}$concentration of the acidic leach solution: $0.5 \mathrm{M}$; $\mathrm{Co}(\mathrm{II})$ concentration of the acidic leach solution: $1006 \mathrm{mg} / \mathrm{L} ; \mathrm{pH}$ of the acidic leach solution: 4.0; phase ratio: 1.0; equilibration time 5 $\min$.

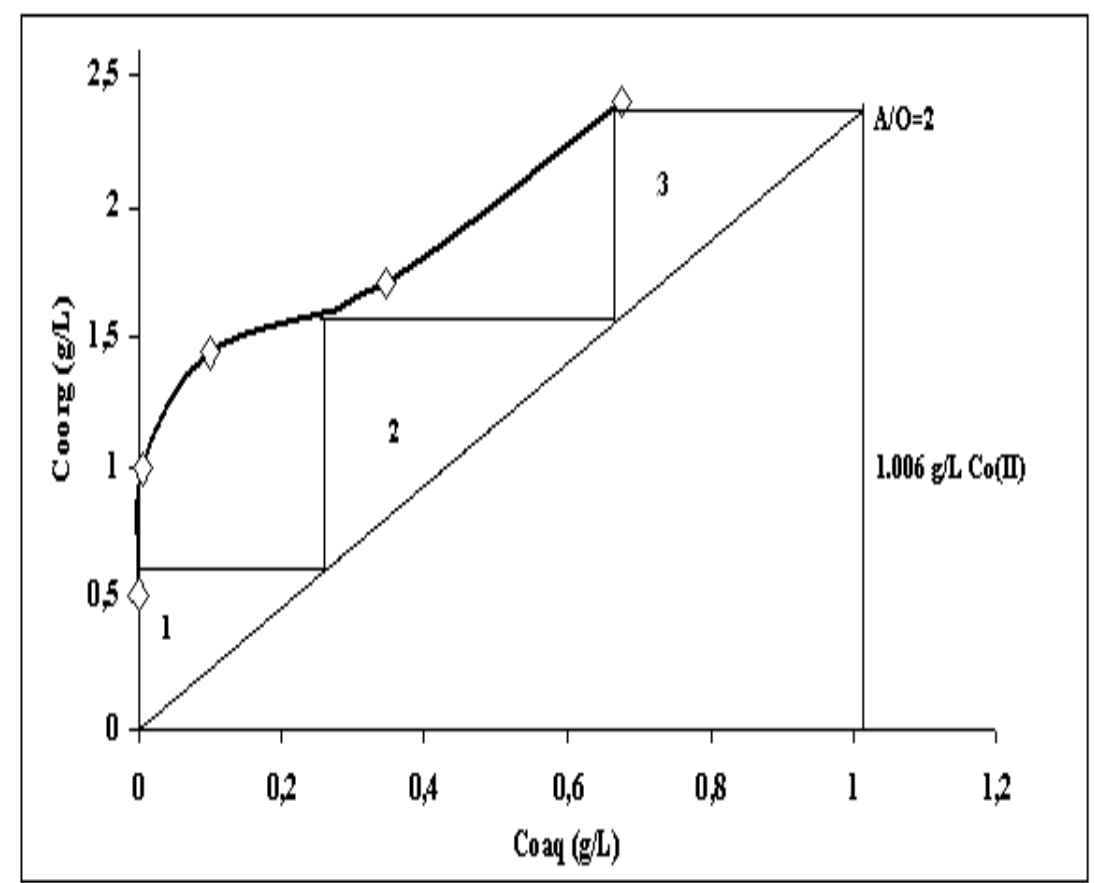

Figure 11. McCabe-Thiele plot of $\mathrm{Co}(\mathrm{II})$ extraction (TOA: $1.5 \%(\mathrm{v} / \mathrm{v})$; toluene: $98.5 \%(\mathrm{v} / \mathrm{v}) ; \mathrm{SCN}^{-}$ concentration of the acidic leach solution: $0.5 \mathrm{M}$; $\mathrm{Co}$ (II) concentration of the acidic leach solution: 1006 $\mathrm{mg} / \mathrm{L} ; \mathrm{pH}$ of the acidic leach solution: 4.0; phase ratio: 1.0; equilibration time $5 \mathrm{~min}$. 


\subsection{Effect of stripping reagent concentration}

$\mathrm{Co}$ (II) was stripped from organic phase (5\%(v/v) TOA in toluene) containing $1052 \mathrm{mg} / \mathrm{L} \mathrm{Co}$ (II) and $1065 \mathrm{mg} / \mathrm{L} \mathrm{Ni}$ (II) using $\mathrm{NH}_{3}$ and TEA as stripping reagents in the range from $1.0 \mathrm{M}$ to $6.0 \mathrm{M}$. The results are shown in Fig 13. In case of TEA as a stripping reagent, the stripping of $\mathrm{Co}$ (II) remained around $5 \%$ with increasing TEA concentration. On the other hand, in the case of $\mathrm{NH}_{3}$, the stripped $\mathrm{Co}$ (II) percentage increases with increasing in $\mathrm{NH}_{3}$ concentration and reaches approximately $90 \%$ at $5.0 \mathrm{M} \mathrm{NH}_{3}$. From these results, it is clear that $\mathrm{NH}_{3}$ is the best stripping reagent and TEA is the poorest stripping reagent at these experimental conditions.

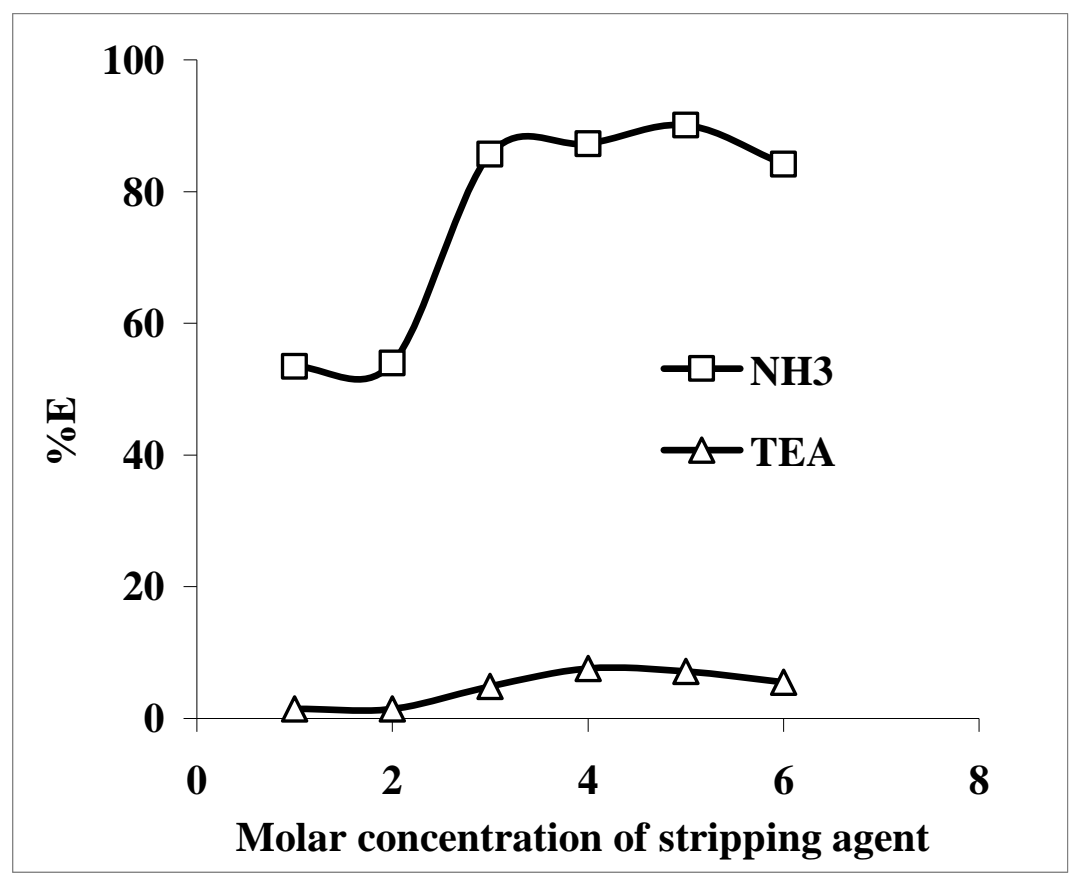

Figure 12. Effect of stripping agent concentration (TOA: $5.0 \%(\mathrm{v} / \mathrm{v})$; toluene: $95 \%(\mathrm{v} / \mathrm{v}) ; \mathrm{SCN}^{-}$ concentration of the acidic leach solution: $0.5 \mathrm{M}$; $\mathrm{Co}$ (II) concentration of the loaded organic phase: 1052 $\mathrm{mg} / \mathrm{L}$; $\mathrm{pH}$ of the acidic leach solution: 4.5; phase ratio: 1.0; equilibration times $5 \mathrm{~min}$.

\subsection{Reuse of the solvent}

To evaluate the reusability of the organic phase, the Co(II)-free (stripped) solventwas applied to the extraction of $\mathrm{Co}(\mathrm{II})$ ions under the optimized conditions. It was found that $99 \%$ of the $\mathrm{Co}(\mathrm{II})$ ions were extracted from the aqueous phase $(1052 \mathrm{mg} / \mathrm{L} \mathrm{Co}$ (II) ions in $20 \mathrm{~mL}, \mathrm{pH} 4.5)$ to the organic phase. After three extraction/stripping cycles, the organic phase had lost little of its volume and retained high extraction efficiency $(97.2 \%)$. In addition, $88.2 \%$ of the extracted metal ions were stripped from the metal-loaded solvent using $5.0 \mathrm{M} \mathrm{NH}_{3}$ solution. 


\subsection{Effect of the optimum conditions on extraction of cobalt and nickel}

The optimum conditions were experimentally determined and were shown in Table 1. At the optimum conditions, the extraction of $\mathrm{Co}(\mathrm{II})$ and $\mathrm{Ni}(\mathrm{II})$ for the five feed mixtures of equimolar compositions are given in Fig. 14. The extraction of $\mathrm{Co}(\mathrm{II})$ are $99.9 \%, 99.5 \%, 93 \%, 83 \%$, and $78 \%$ for the five feed mixtures of $500 \mathrm{mg} / \mathrm{L} \mathrm{Co}+500 \mathrm{mg} / \mathrm{L} \mathrm{Ni}, 1000 \mathrm{mg} / \mathrm{L} \mathrm{Co}+1000 \mathrm{mg} / \mathrm{L} \mathrm{Ni}$, and $1500 \mathrm{mg} / \mathrm{L} \mathrm{Co}+1500 \mathrm{mg} / \mathrm{L}$ $\mathrm{Ni}, 2000 \mathrm{mg} / \mathrm{L} \mathrm{Co}+2000 \mathrm{mg} / \mathrm{L} \mathrm{Ni}, 3000 \mathrm{mg} / \mathrm{L} \mathrm{Co}+3000 \mathrm{mg} / \mathrm{L}$ within $5 \mathrm{~min}$, respectively. On the other hand, for the same feed mixtures the extraction of $\mathrm{Ni}(\mathrm{II})$ were found to be of $2.4 \%, 0.4 \%$, and $0.6 \%$, $0.34 \%, 0.36 \%$, respectively.

Table 1. Optimum conditions for the extraction of $\mathrm{Co}(\mathrm{II})$

\begin{tabular}{|c|c|}
\hline Parameter & Value \\
\hline Equilibration time & $5 \mathrm{~min}$ \\
\hline $\begin{array}{c}\text { SCN concentration of the } \\
\text { acidic leach solution }\end{array}$ & $0.5 \mathrm{M}$ \\
\hline $\mathrm{pH}$ of the acidic leach solution & 4.5 \\
\hline Stripping solution cons. & $5 \mathrm{M} \mathrm{NH}_{3}$ solution \\
\hline Mixing speed & $1000 \mathrm{rpm}$ \\
\hline Extractant $(\mathrm{TOA})$ & $5 \%(\mathrm{v} / \mathrm{v})$ \\
\hline Diluent $($ Toluene) & $95 \%(\mathrm{v} / \mathrm{v})$ \\
\hline Phase ratio $\left(V_{o} / V_{a q}\right)$ & 2.0 \\
\hline
\end{tabular}

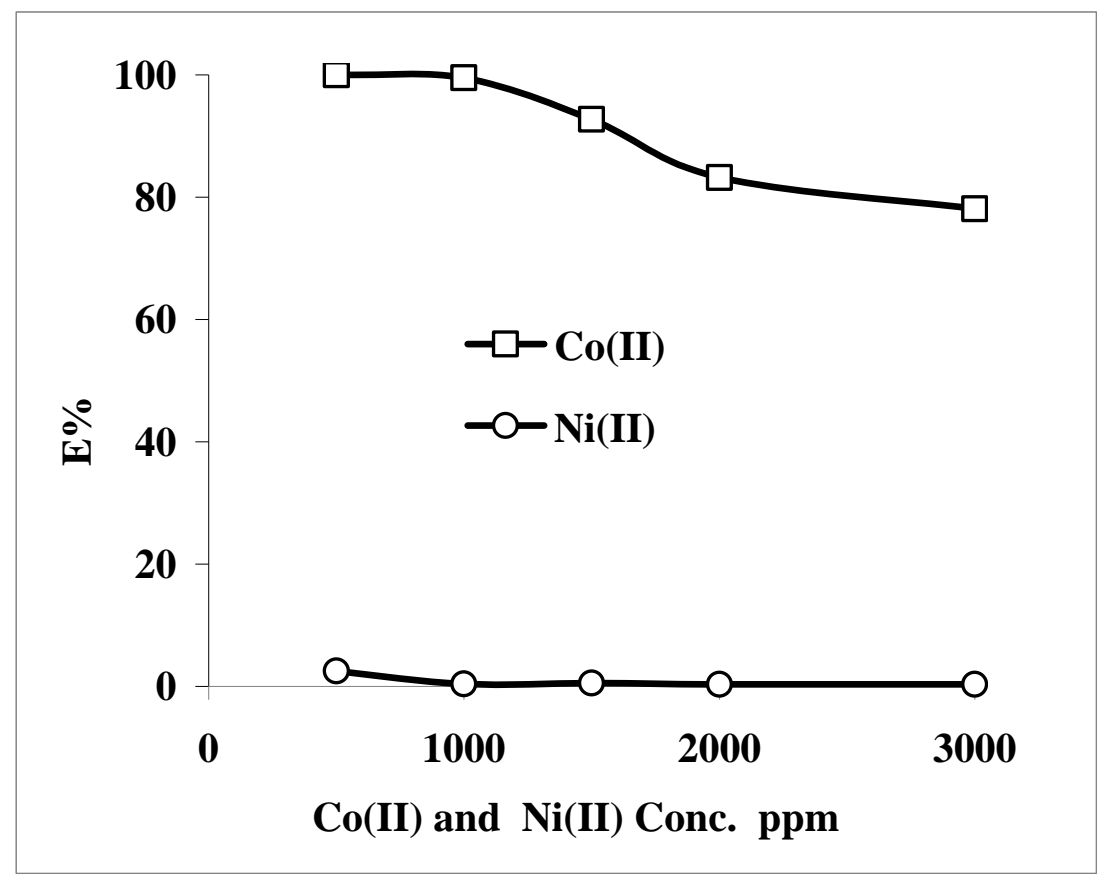

Figure 13. Effect of metal concentration at the optimum condition (TOA: $5.0 \%(\mathrm{v} / \mathrm{v})$; toluene: $95 \%(\mathrm{v} / \mathrm{v})$; $\mathrm{SCN}^{-}$concentration of the acidic leach solution: $0.5 \mathrm{M}$; $\mathrm{Co}(\mathrm{II})$; $\mathrm{pH}$ of the acidic leach solution: 4.5; phase ratio: 2.0; equilibration times $5 \mathrm{~min}$. 


\subsection{SX process selectivity}

Under the optimum conditions, the separation factors of cobalt and nickel for five feed mixtures of equimolar compositions were given in Table 2 . Clearly, there is significantly greater cobalt extraction than nickel under these conditions. The separation factor, $\beta_{\mathrm{Co} / \mathrm{Ni}}$, was calculated using Eq (6).

$$
\beta_{\mathrm{Co} / \mathrm{Ni}}=\frac{\mathrm{D}_{\mathrm{Co}}}{\mathrm{D}_{\mathrm{Ni}}}
$$

where $D_{\mathrm{Co}}$ and $D_{\mathrm{Ni}}$ are the distribution coefficient of Co and $\mathrm{Ni}$ between organic and aqueous phases respectively. Distribution coefficient at the end of the $5 \mathrm{~min}$ and separation factors were given in Table 2 . Clearly, the system is extremely selective for cobalt, especially within the short contact time used at higher starting concentrations.

Table 2. Separation factors for the extraction of $\mathrm{Co}(\mathrm{II})$

\begin{tabular}{|c|c|c|}
\hline \multirow[b]{2}{*}{ Feed mixture } & \multicolumn{2}{|c|}{$\beta_{\mathrm{Co} / \mathrm{Ni}}$} \\
\hline & \multicolumn{2}{|c|}{$5 \mathrm{~min}$} \\
\hline $500 \mathrm{mg} / \mathrm{L} \mathrm{Co}+500 \mathrm{mg} / \mathrm{L} \mathrm{Ni}$ & \multicolumn{2}{|c|}{$>10000$} \\
\hline $1000 \mathrm{mg} / \mathrm{L} \mathrm{Co}+1000 \mathrm{mg} / \mathrm{L} \mathrm{Ni}$ & \multicolumn{2}{|c|}{2404} \\
\hline $1500 \mathrm{mg} / \mathrm{L} \mathrm{Co}+1500 \mathrm{mg} / \mathrm{L} \mathrm{Ni}$ & \multicolumn{2}{|c|}{402} \\
\hline $2000 \mathrm{mg} / \mathrm{L} \mathrm{Co}+2000 \mathrm{mg} / \mathrm{L} \mathrm{Ni}$ & \multicolumn{2}{|c|}{316} \\
\hline $3000 \mathrm{mg} / \mathrm{L} \mathrm{Co}+3000 \mathrm{mg} / \mathrm{L} \mathrm{Ni}$ & \multicolumn{2}{|c|}{161} \\
\hline \multirow[b]{3}{*}{ Feed mixture } & \multicolumn{2}{|c|}{$D$; Distribution Coefficient } \\
\hline & $D_{C o}$ & $D_{N i}$ \\
\hline & $5 \mathrm{~min}$ & $5 \mathrm{~min}$ \\
\hline $500 \mathrm{mg} / \mathrm{L} \mathrm{Co}+500 \mathrm{mg} / \mathrm{L} \mathrm{Ni}$ & 5119 & 0,016 \\
\hline $1000 \mathrm{mg} / \mathrm{L} \mathrm{Co}+1000 \mathrm{mg} / \mathrm{L} \mathrm{Ni}$ & 200 & 0,083 \\
\hline $1500 \mathrm{mg} / \mathrm{L} \mathrm{Co}+1500 \mathrm{mg} / \mathrm{L} \mathrm{Ni}$ & 13 & 0,032 \\
\hline $2000 \mathrm{mg} / \mathrm{L} \mathrm{Co}+2000 \mathrm{mg} / \mathrm{L} \mathrm{Ni}$ & 5 & 0,016 \\
\hline $3000 \mathrm{mg} / \mathrm{L} \mathrm{Co}+3000 \mathrm{mg} / \mathrm{L} \mathrm{Ni}$ & 4 & 0,022 \\
\hline
\end{tabular}

\section{Conclusions}

A solvent extraction process using TOA to separate and concentrate cobalt from an acidic thiocyanate leach solution has been investigated. From this study the following conclusions can be drawn:

1. The optimum conditions have been determined experimentally as stated above Table 1 .

2. The highest extraction efficiency was obtained when $\mathrm{pH}$ and $\mathrm{SCN}^{-}$concentration of the acidic thiocyanate leach solution were 4.5 and $0.5 \mathrm{M}$ respectively.

3. Extraction efficiency increased by increasing the extractant (TOA) concentration which stabilised at an excess of the TOA in the organic phase.

4. A higher concentration of $\mathrm{NH}_{3}$ in the stripping solution increased the concentration driving force, hence, stripping efficiency also increased.

5. From the application point of view, toluene could be a good choice for practical purpose for dilution of TOA. 
6. Based on the analysis of $\log D$ and $\operatorname{logarithm}$ of the reactive species the extraction and stripping reaction sitochiometries were explained. The following equations has been concluded for the extraction and the stripping of $\mathrm{Co}(\mathrm{II})-\mathrm{TOA}$ and $\mathrm{Co}(\mathrm{II})-\mathrm{NH}_{3}$ complexes.

7. Extraction reaction:

$$
2 \mathrm{R}_{3} \mathrm{~N}_{(\text {org })}+2 \mathrm{H}_{(\mathrm{aq})}^{+}+\mathrm{Co}_{(\mathrm{aq})}^{2+}+4 \mathrm{SCN}_{(\mathrm{aq})}^{-} \Leftrightarrow\left[\left(\mathrm{R}_{3} \mathrm{NH}\right)_{2} \mathrm{Co}(\mathrm{SCN})_{4}\right]_{(\mathrm{org})}
$$

Stripping reaction:

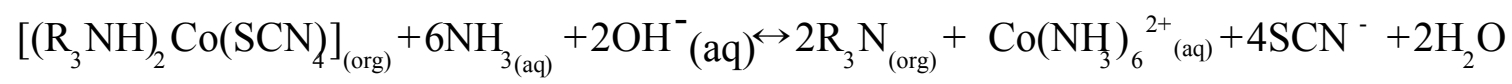

\section{Acknowledgement}

The financial support of this work was provided by scientific research research commission of Sakarya University (BAPK), Project No. 2009-50-02-012 is gratefully acknowledged.

\section{References}

1) R. A. Kumbasar, Sep. Purif. Technol., 64, 273-279 (2009).

2) B.R Reddy, C. Parija, B. Sarma, Hydrometallurgy, 53, 11-17 (1999).

3) K. Dimitrov, V. Rollet, A. Saboni, S. Alexandrova, Sep. Sci. Technol., 40, 2111-2123 (2005).

4) R. A. Kumbasar, J. Membr. Sci. 333, 118-124 (2009).

5) G. M. Ritcey, A. W. Ashbrook,. Solvent Extraction: Principles and Applications to Process Metallurgy Part 2 (1979), Elsevier, Amsterdam, Netherlands.

6) C. Y. Cheng, Hydrometallurgy, 56, 369-386 (2000).

7) C. A. Nogueira, F. Delmas, Hydrometallurgy 52, 267-287(1999).

8) N. V. Thakur, S. L. Mishra, Hydrometallurgy, 48, 277-289(1998).

9) S.V. Mahamuni, S.S. Kolekar, P.P. Wadgaonkar, M.A. Anuse, J. Iran. Chem. Soc. 6, 200-212 (2009).

10) A. Mellah, D. Benachour, Chem. Eng. Process., 45, 684-690 (2006).

11) N. I. Gerhard, Plant, A.A. Petrova, V.A., R.K Tagirov, Hydrometallurgy, 60, 1-5(2001).

12) J. Saji, T.P. Rao, C.S.P. Iyer, M.L.P. Reddy, Hydrometallurgy, 49, $289-296$ (1998).

13) N.A. Sayar, M. Filiz., A.A. Sayar, Hydrometallurgy, 96, 148-153 (2009).

14) M. Kobya, C. Aydiner, E. Demirbas, Desalination, 175, 237-246(2005).

15) F. Asrafi, A. Feyzbakhsh, N. E. Heravi, International J. ChemTech Res., 1, 420-425 (2009).

16) S. Sanuki, M. Jyumonji, H. Majima, Hydrometallurgy, 55, 119-136 (2000).

17) M. Jung Jung, P. Venkateswaran, Y. S. Lee, J. Ind. Eng. Chem., 14, 110-115 (2007).

18) C. Bourget, B. Jakovljevic, D. Nucciarone, Hydrometallurgy, 77, 203-218 (2005).

19) P. E. Tsakiridis, S. L. Agatzini, Hydrometallurgy, 72, 269-278 (2004).

20) J. S. Preston, Sep. Sci. Technol., 17, 1697-1718 (1982).

21) A. Cerpa, F. J. Alguacil, Chem. Technol. Biotechnol., 79, 455 (2004).

22) M.S. Uddin, M. Kathiresan, Sep. Purif. Technol., 19, 3-9 (2000).

23) R.R. Amirov, Russ. J. Coord. Chem., 29, 559-563 (2003).

24) T. Zhu, Hydrometallurgy, 27, 231-245 (1991). 